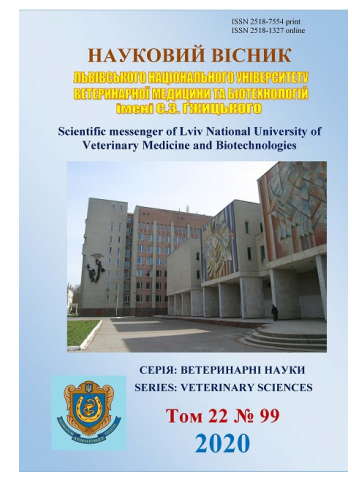

\author{
Науковий вісник Дьвівського національного університету \\ ветеринарної медицини та біотехнологій імені С.3. Гжицького. \\ Серія: Ветеринарні науки \\ Scientific Messenger of Lviv National University \\ of Veterinary Medicine and Biotechnologies. \\ Series: Veterinary sciences
}

UDC 619:616.99:595.421

\title{
Comparative effectiveness of acaricides
}

\author{
V. A. Levytska
}

State Agrarian and Engineering University in Podilia, Kamianets-Podilskyi, Ukraine

Article info

Received 27.08.2020 Received in revised form 23.09.2020 Accepted 24.09.2020

State Agrarian and Engineering University in Podilia,

Shevchenko Str., 13, KamianetsPodilskyi, 32300, Ukraine. Tel.: +38-067-381-20-12 E-mail: Levytska28@gmail.com
Levytska, V. A. (2020). Comparative effectiveness of acaricides. Scientific Messenger of Lviv National University of Veterinary Medicine and Biotechnologies. Series: Veterinary sciences, 22(99), 3-7. doi: 10.32718/nvlvet9901

The use of chemicals is the main method of controlling ectoparasites around the world. In Ukraine, due to the lack of an effective system for controlling ixodid ticks, there is an annual increase in the number of tick-borne diseases. Prevention of tick bites is largely based on the use of chemical repellents and acaricides. The study was conducted in 2019 in the laboratory of parasitology of the Department of Infectious and Invasive Diseases FVMTT PDATU. The experiments used neonicotinoids - imidacloprid, phenyl pyrazole - fipronil, pyrethroid compounds - cyfluthrin, permethrin. In the first phase of the studies, acetone was used as a diluent, each acaricide was diluted to obtain a $1.0 \%$ solution, after which 10-fold dilutions of each acaricide from 1:10 to 1:107 were prepared and the study was performed. In the second stage of research, the method of topical application of acetone solutions of different concentrations was used. Cyfluthrin caused $100 \%$ death of ticks of D. reticulatus and I. ricinus within 24 hours at a dilution of up to 1:10.000. Statistical analysis showed that ticks of the two species were significantly more sensitive to cyfluthrin and permethrin than to fipronil and imidacloprid, based on $L D_{50}$ values. According to the level of contact activity, which is determined by topical application and the estimated LD50, cyfluthrin against I. ricinus was the most active acaricide and $L D_{50}$ was $0.33 \pm 0.07$. In relation to D. reticulatus, the $L D_{50}$ of cyfluthrin was $0.51 \pm 0.08$. After contact with cyfluthrin, $40 \%$ of I. ricinus ticks and $30 \%$ of D. reticulatus ticks died within one hour, and after 24 hours all ticks were dead. Among the adult stages of ixodid ticks, males were more resistant to the drugs than females. Therefore, cyfluthrin is recommended for the controling of ticks, which ensures the death of mites after a short period of time.

Key words: ixodid ticks, Ixodes ricinus, Dermacentor reticulatus, acaricides, efficiency.

\section{Порівняльна ефективність окремих акарицидів}

\author{
В. А. Левицька
}

Подільський державний аграрно-технічний університет, м. Кам'янець-Подільський, Україна

Застосування хімічних речовин є основним методом боротьби з ектопаразитами у всьому світі. В Україні через відсутність розробленої ефективної системи боротьби з іксодовими кліщами щуорічно спостерігається збільшення кількості трансмісивних хвороб. Профілактика укусів кліщів значною мірою заснована на застосуванні хімічних репелентів та акарицидів. Дослідження проведено протягом 2019 року в умовах лабораторії паразитологї̈ кафедри інфекиійних та інвазійних хвороб ФВМТТ ПДАТУ. У дослідах використані неонікотиноїди - імідаклоприд, фінілпіралізоли - фіпроніл, піретроїдні з'єднання - циифлутрин, перметрин. На першому етапі досліджень використовували ачетон як розріджувач, кожен акарицид розбавляли для отриманням 1 \% розчину, після чого готували 10-кратні розведення кожного акарициду від 1:10 до 1:107 і проводили дослідження. На другому етапі досліджень був використаний метод топікального нанесення ачетонових розчинів різної концентраиї. Цифлутрин спричиняв 100 \% загибель кліщів виду D. reticulatus ma I. ricinus протягом 24 годин при розведенні до 1: 10 000. Статистичний аналіз показав, щзо клімі двох видів були значно чутливішими до ичфлутрину та перметрину, ніж до фіпронілу та імідоклоприду, на основі значень ЛД5о. За рівнем контактної активності, яка визначається топікальним нанесеням і оцінюваної ЛД50, циифлтрин щзодо І. гісіпия був

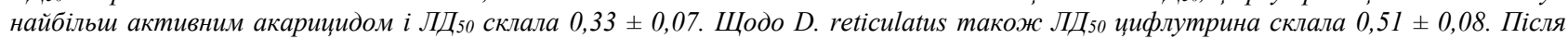
контакту з циифлутрином вже через одну годину загинуло 40 \% кліщчів I. ricinus $i 30$ \% кліщів D. reticulatus, a через добу всі кліщі 
були мертвими. Серед імагінальних стадій іксодид самиі виявились стійкішими до дї̈ препаратів, ніж самки. Отже, для знищення кліщів рекомендовано циифлутрин, який забезпечує вже через короткий проміжок часу загибель кліщів.

Ключові слова: іксодові кліші, Ixоdes ricinus, Dermacentor reticulatus, акарицидна ефективність

\section{Вступ}

Застосування хімічних речовин $є$ основним методом боротьби з ектопаразитами в усьому світі. В Україні через відсутність розробленої ефективної системи боротьби з іксодовими кліщами щорічно спостерігається збільшення кількості трансмісивних хвороб. Внаслідок цього як сільськогосподарські, так і домашні тварини зазнають збитків від вірусних, бактеріальних, рикетсіозних та паразитарних захворювань. Велика увага приділяється лікуванню цих захворювань, однак проблема боротьби 3 переносникамикліщами в основному залишається без уваги (Samish et al., 2004; Walker, 2014; Levytska et al., 2019).

В даний час профілактика укусів членистоногих в основному досягається за рахунок знищення кліщів та запобігання їх нападу. Профілактика укусів кліщів значною мірою заснована на застосуванні хімічних репелентів та акарицидів. Однак розвиток стійкості серед кліщів, забруднення навколишнього середовища та забруднення м'яса й молока худоби є основними проблемами при використанні цих засобів (George et al., 2004; Abbas et al., 2014).

Акарицидами називають хімічні речовини, які знищують кліщів. Розрізняють дві групи акарицидів: специфічні, що діють тільки на кліщів, і неактивні проти інших членистоногих та інсектоакарициди, що мають активність не тільки щодо кліщів, а й щодо комах. Специфічні акарициди, володіють вибірковою дією щодо кліщів паразитів рослин і не володіють активністю щодо іксодових кліщів (Mel'nikov et al., 1995). Очевидно, така вибірковість є наслідком глибоких еволюційних перебудов в організмі кліщів, у яких в процесі еволюції сформувалися різні типи харчування: соками рослин або кров'ю хребетних тварин. Відомо, що гематофаги - іксодові кліщі проявляють чутливість до багатьох інсектоакарицидів 3 різних груп хімічних сполук (Endris et al., 2000).

За характером дії на організм членистоногих інсектоакарициди поділяються на: контактні, які діють при безпосередньому потраплянні на покриви тіла або при контакті членистоногих 3 обробленою поверхнею; кишкові, які проникають в організм членистоногих при харчуванні через органи травлення; фуміганти, що перебувають в повітрі у вигляді пари та димів і потрапляють в організм членистоногих через дихальну систему (Burridge et al., 2003).

Цифлутрин належить до групи синтетичних піретроїдів третього покоління, вибірково зв'язується 3 рецепторами нервових клітин комах та порушує роботу натрієвих каналів нервових клітин, що призводить до затримки реполяризації мембран, гальмування нервових імпульсів, порушення координації рухів, паралічу і швидкої загибелі комах. Перметрин - інсектицид, акарицид. Належить до групи піретроїдів також. Удосконалення хімічної будови піретроїдів призвело до створення сполук, що володіють високою інсектицидною і акарицидною активністю, відносно тривалою залишковою дією і фотостабільністю. Піретроїди поділяють на два типи. До першого типу належать піретрини і піретроїди: перметрин, тетраметрин, біоаллетрин, ресметрин, фенотрин та ін. У всіх цих сполук присутня центральна компонента -COOCH2-, i вони викликають у комах гіперактивність, тремор, а потім нокдаун, який може бути оборотним. Піретроїди першого типу називають неціанвмісними. Піретроїди другого типу - циперметрин, дельтаметрин, фенвалерат і ін. У всіх цих сполук центральної компонентою є -COOCHCN-, і вони викликають у комах гіперактивність, втрату координації, конвульсії, нокдаун, який завжди $є$ незворотним. Піретроїди другого типу називають ціанвмісними. Загалом сполуки, що містять ціаногрупу в центральній компоненті, більш токсичні для теплокровних (Izmerova, 1989).

В останні 30 років відбувається бурхливий ріст обсягу виробництва піретроїдів і розширення їхнього асортименту, оскільки ця група сполук більше за інших відповідає критеріям ефективності та безпеки.

Фіпроніл належить до інсектоакарацидів групи фенілпіразолів. Селективно блокує роботу ГАМКзалежних хлор-іонних каналів в мембранах нервових клітин членистоногих, що призводить до порушення передачі нервових імпульсів, конвульсії та загибелі ектопаразитів.

Імідаклоприд - інсектицид 3 класу неонікотиноїдів, який найбільш широко застосовується. Механізм дії - зв'язується 3 постсинаптичними нікотиновими ацетилхоліновими рецепторами центральної нервової системи комах, в результаті чого у них розвиваються паралічі й конвульсії, що приводять до загибелі (Peter et al., 2005).

Метою роботи була оцінка дії на кліщів Ixodes ricinus та Dermacentor reticulatus акарицидів різних класів хімічних сполук, перспективних для використання у тваринництві.

\section{Матеріал і методи досліджень}

Дослідження проведено протягом 2019 року в умовах лабораторії паразитології кафедри інфекційних та інвазійних хвороб ФВМТТ ПДАТУ. Кліщів збирали у природніх біотопах Хмельницької області на прапор та ідентифікували за загальноприйнятими методиками і визначниками.

У дослідах використані неонікотиноїди - імідаклоприд, фінілпіралізоли - фіпроніл, піретроїдні з'єднання - цифлутрин, перметрин. На першому етапі досліджень використовували ацетон як розріджувач, кожен акарицид розбавляли для отриманням $1 \%$ розчину, після чого готували 10-кратні розведення кожного акарициду від 1:10 до 1:107. По 0,5 мл кожного розчину кожного акарициду наносили піпетками у скляні чашки Петрі, закривали кришкою та обертаючи всі внутрішні поверхні чаші зрошували розведе- 
ним акарицидом. Коли всі поверхні були вологими, надлишок розведеного акарициду виливали і чашку Петрі висушували на повітрі. У контрольній групі використовували лише ацетон. Для кожного досліджуваного виду кліщів по 20 дорослих кліщів поміщали в кожну чашку Петрі з акарицидом, яку потім закривали кришкою, обладнаною отворами для повітря, та інкубували при $24{ }^{\circ} \mathrm{C}$. Після цього проводили спостереження за кліщами протягом 24 год.

На другому етапі досліджень був використаний метод топікального нанесення ацетонових розчинів різної концентрації (Metodicheskie ukazanija, 2004). Токсичність сполук в даному випадку характеризується величиною летальної дози (ЛД), яка виражається в мкг акарициду по ДР на 1 г маси членистоногих. Ця величина відповідає кількості токсину, який викликає заданий відсоток загибелі досліджуваного об'єкта. Ми розраховували показник ЛД 0 як дозу акарициду, що викликає загибель 50 \% кліщів, при топікальному нанесенні акарициду в мкг/г. У наших експериментах ми наносили на дорсальну поверхню кліщів краплю обсягом 0,5 мкл. При вивченні кожного акарициду використовували ті ж концентрації, що описані вище. В контрольній групі використовували дистильовану воду. Після нанесення розчину кліщів поміщали в стерильні чашки Петрі та спостерігали протягом доби. Облік результатів досліджень проводили кожної години протягом доби. Всі досліди проводили в групах, в кожній по 20 кліщів. Дані оброблені за допомогою аналізу за стандартною методикою (Popov, 1965).

Життєздатність кліщів визначали за допомогою мікроскопії (Konus 5605 Biorex-3), враховуючи рухову реакцію при подразненні. Критерієм загибелі кліщів вважали відсутність рухливості та відсутність реакції на механічні подразники.

\section{Результати досліджень}

Цифлутрин спричиняв 100 \% загибель кліщів виду D. reticulatus протягом 24 годин при розведенні $1: 10000$. Подібним чином перметрин спричиняв $100 \%$ загибель - протягом 24 годин при розведенні
1:1000. На відміну від цього імідаклоприд не призвів до загибелі всіх кліщів протягом 24 годин навіть при найменшому розведенні (1:100). Статистичний аналіз показав, що кліщі виду D. reticulatus були значно чутливішими до цифлутрину та перметрину, ніж до фіпронілу та імідоклоприду, на основі значень ЛД 5 .

Повна 100 \% загибель кліщів виду I. ricinus була досягнута протягом 24 годин розчином цифлутрину у розведенні 1:10 000, перметрином у розведенні до 1:1 000 та фіпронілом лише у нерозведеному продукті. Знову ж таки, імідаклоприд не призвів до $100 \%$ загибелі кліщів виду Ixodes ricinus протягом 24 годин навіть при найменшому розведенні розчину (1:100). Статистичний аналіз показав, що дорослі кліщі виду I. ricinus були найбільш чутливими до цифлутрину порівняно з усіма іншими акарицидами, випробуваними на основі значень ЛД 5 . Наступним найбільш ефективним акарицидом був перметрин. Фіпроніл та імідаклоприд були найменш ефективними акарицидами проти дорослих кліщів виду I. ricinus.

Загибель кліщів настала значно швидше після їхнього контакту 3 цифлутрином і перметрином, ніж 3 іншими дослідженими препаратами. За рівнем контактної активності, яка визначається топікальним нанесеням, і оцінюваної ЛД 50 , цифлутрин щодо I. ricinus був найактивнішим акарицидом i ЛД 50 склала 0,33 \pm 0,07 мкг/г. Щодо D. reticulatus також ЛД цифлутрина склала $0,51 \pm 0,08$ мкг/г. Після контакту 3 цифлутрином вже через одну годину загинуло $40 \%$ кліщів $I$. ricinus і $30 \%$ кліщів D. reticulatus, а через добу всі кліщі були мертвими. Подібним чином перметрин спричинив $100 \%$ загибель кліщів протягом 24 годин. Після контакту з фіпронілом загибель кліщів через 1 годину становила не більше $10 \%$ і навіть через добу частина кліщів залишилася живою. Після контакту 3 імідаклопридом через добу залишилися живі майже всі кліщі. Порівняльна ефективність акарицидів при знищенні кліщів наведена в таблиці 1. Статистичний аналіз показав, що як самці, так і самки обох видів кліщів були значно чутливішими до цифлутрину та перметрину, ніж до фіпронілу та імідоклоприду.

\section{Таблиця 1}

Дослідження акарицидної дії хімічних речовин на кліщів виду Ixodes ricinus та Dermacentor reticulatus при топікальному нанесенні

\begin{tabular}{|c|c|c|c|c|c|c|}
\hline \multirow{2}{*}{$\begin{array}{c}\text { Хімічна } \\
\text { речовина }\end{array}$} & \multicolumn{2}{|c|}{ Загинуло кліщів через 15 хв, \% } & \multicolumn{2}{|c|}{ Загинуло кліщів через 1 год, \% } & \multicolumn{2}{|c|}{ Загинуло кліщів через 24 год, \% } \\
\hline & Самки & Самці & Самки & Самці & Самки & Самці \\
\hline \multicolumn{7}{|c|}{ Dermacentor reticulatus } \\
\hline Цифлутрин & 0 & 0 & 40 & 40 & 100 & 100 \\
\hline Перметрин & 10 & 10 & 30 & 20 & 100 & 100 \\
\hline Імідаклоприд & 0 & 0 & 0 & 0 & 10 & 10 \\
\hline Фіпроніл & 0 & 0 & 10 & 0 & 40 & 20 \\
\hline Контроль & 0 & 0 & 0 & 0 & 0 & 0 \\
\hline \multicolumn{7}{|c|}{ Ixodes ricinus } \\
\hline Цифлутрин & 10 & 0 & 50 & 30 & 100 & 100 \\
\hline Перметрин & 0 & 10 & 40 & 20 & 100 & 100 \\
\hline Імідаклоприд & 0 & 0 & 10 & 10 & 20 & 10 \\
\hline Фіпроніл & 0 & 0 & 10 & 10 & 40 & 30 \\
\hline Контроль & 0 & 0 & 0 & 0 & 0 & 0 \\
\hline
\end{tabular}


Рухова активність кліщів обох видів при контакті 3 імідаклопридом та фіпронілом в перші 3 хвилини після контакту з ними не змінилася. Стан нокдауна не було зареєстровано в першу годину після контакту. Ці дані дозволяють припускати, що процес отруєння кліщів після контакту з хімічними сполуками не наступає в першу годину. Однак рухова активність кліщів обох видів значно змінилась вже в перші хвилини після контакту 3 цифлутрином. Кліщі обох видів I. ricinus та D. reticulatus вже в перші 3 хвилини почали рухатися достовірно повільніше (приблизно в 2 рази).

Серед імагінальних стадій іксодид самці виявились стійкішими до дії препаратів, ніж самки.

Кліщі з групи контролю лишалися живими протягом всього експерименту, що підтверджувалося руховими реакціями.

\section{Обговорення}

Членистоногі відіграють важливу роль у патологіях людини і тварин - починаючи від запалень, спричинених укусом, а також алергічних реакцій до складних захворювань, які можуть спричинити зниження продуктивності або навіть і загибель тварини. При виборі засобів захисту від іксодових кліщів необхідно враховувати ризики, пов'язані з патогенами, які можуть переносити кліщі, а також стійкість кліщів до певних хімічних речовин.

У попередніх дослідженнях, проведених в США та Європі, було встановлено, що синтетичні піретроїди є ефективними проти кліщів роду Ixodes. Ефективна концентрація цих сполук коливалась від $0,004 \mathrm{мг} / \mathrm{cm}^{2}$ до 0,25 мг/см². Було встановлено, що період впливу на кліщів коливався від 10 секунд до 1 години, що призводило до знешкодження або загибелі $>90$ \% личинок, німф та дорослих видів Ixodes. Крім того, дані хімічні сполуки мають накопичувальну дію на поверхнях і в подальшому можуть забезпечувати ефективний захист від паразитів. Ця дія залежить від концентрації речовини, а також часу дії препарату на кліщів (Lane, 1989; Kocisova \& Para, 1999). В наших дослідженнях було продемонстровано, що цифлутрин i перметрин, які належать до групи синтетичних піретроїдів, $\epsilon$ найефективнішими для знищення кліщів протягом доби. Також варто зазначити, що дія починалась в першу годину, що є важливим фактором для захисту від укусів кліщів.

Дослідниками встановлено, що сприйнятливість до піретроїдів серед кліщів зростає зі збільшенням віку кліща. Крім того, важливим є те, що при обробці акарицидами іксодових кліщів можливе зменшення кількості відкладених самками яєць, зменшення числа личинок, що вилуплюються, і т. д. Ці явища були характерними для багатьох видів іксодових кліщів і при використанні різних речовин (McCosker, 1979; FAO, 1990; Endris et al., 2000).

\section{Висновки}

Отже, для знищення кліщів рекомендовано цифлутрин, який забезпечує вже через короткий проміжок часу загибель кліщів. Важливо, що кліщі при цьому стають менш активними, що відповідає основним вимогам щодо акарицидних речовини. Дана сполука володіє вираженою акарицидною дією на іксодових кліщів та вже через добу забезпечує 100 \% ефективне знищення кліщів. Планується подальше проведення досліджень препарату “Цифлур-комбі” у виробничих умовах.

\section{References}

Abbas, R. Z., Zaman, M. A., Colwell, D. D., Gilleard, J., \& Iqbal, Z. (2014). Acaricide resistance in cattle ticks and approaches to its management: the state of play. Vet Parasitol, 203(1-2), 6-20. doi: 10.1016/j.vetpar.2014.03.006.

Burridge, M. J., Simmons, L.-A., \& Allan, S. A. (2003). Efficacy of acaricides for control of four tick species of agricultural and public health significance in the United States. Journal of Agricultural and Urban Entomology, 20, 207-219. URL: http://scentsoc.org/ Volumes/JAUE/v20/207.pdf.

Endris, R. G., Matthewson, M. D., Cooke, M. D., \& Amodie, D. (2000). Repellency and efficacy of $65 \%$ permethrin and $9.7 \%$ fipronil against Ixodes ricinus. Vet Ther., 1(3), 159-168. URL: https://pubmed.ncbi. nlm.nih.gov/19757578.

FAO (1990). Report of the FAO expert consultation on revision of strategies for the control of ticks and tickborne diseases, Rome, 25-29 September 1989. Parassitologia, 32, 3-12.

George, J. E., Pound, J. M., \& Davey, R. B. (2004). Chemical control of ticks on cattle and the resistance of these parasites to acaricides. Parasitology, 129, 353-366. doi: 10.1017/S0031182003004682.

Izmerova, N. F. (1989). Piretroidy. Nauchnye obzory sovetskoj literatury po toksichnosti i opasnosti himicheskih veshhestv. Centr mezhdunarodnyh proektov GKNT, 119, 74 (in Russian).

Kocisova, A., \& Para, L. (1999). Possibilities of longterm protection against blood-sucking insects and ticks. Cent Eur J Pub Hlth, 7(1), 27-30. URL: https://pubmed.ncbi.nlm.nih.gov/10084018.

Lane, R. S. (1989). Treatment of clothing with permethrin spray for personal protection against the western black-legged tick, Ixodes pacificus (Acari: Ixodidae). Exp Appl Acarol, 6(4), 343-352. doi: 10.1007/bf01193304.

Levytska, V. A., Mushynskyi, A. B., \& Berezovskyi, A. V. (2019) Monitorynh transmisyvnykh zakhvoriuvan shcho peredaiutsia iksodovymy klishchamy v zakhidnykh oblastiakh Ukrainy. Naukovyi visnyk LNUVMB im. S. Z. Gzhytskoho, 21(96), 14-18. doi: 10.32718/nvlvet9603 (in Ukrainian).

McCosker, P. J. (1979). Global aspects of the management and control of ticks of veterinary im- 
portance. Recent Adv Acarol, 2, 45-53. doi: 10.1016/B978-0-12-592202-9.50012-4.

Mel'nikov, H. N., Novozhilov, K. V., \& Belan, S. R. (1995). Pesticidy i reguljatory rosta rastenij. Sprav, izd. M.: Himija (in Russian).

Metodicheskie ukazanija (2004). Metody opredelenija jeffektivnosti insekticidov, akaricidov, reguljatorov razvitija i repellentov, ispol'zuemyh $\mathrm{v}$ medicinskoĭ dezinsekcii (MU 3.5.2. 1759-03 ot 28.09.2003 g.). M.: Federal'nyı̌ centr Gossanjepidnadzora Minzdrava Rossii (in Russian).

Peter, R. J., Van den Bossche, P., Penzhorn, B. L., \& Sharp, B. (2005). Tick, fly, and mosquito control - les- sons from the past, solutions for the future. Vet Parasitol, 132, 205-215. doi: 10.1016/j.vetpar.2005.07.004.

Popov, P. V. (1965). Statisticheskij analiz opytnyh dannyh s pomoshh'ju linii regressii "doza pesticida aktivnost". Himija, 10, 72-74 (in Russian).

Samish, M., Ginsber, G. H., \& Glazer, I. (2004). Biological control of ticks. Parasitology, 129, S389-403. doi: 10.1017/S0031182004005219.

Walker, A. R. (2014). Ticks and associated diseases: a retrospective review. Med Vet Entomol, 28(S1), 1-5. doi: $10.1111 /$ mve. 12031 . 